\title{
Longitudinal Relationships between Nutritional Status and Educational Achievements of Ellisras Rural Children in South Africa 南非鄉鎮學童的營養水平與學業成就的關係
}

\author{
M J THEMANE ${ }^{\mathrm{a}}$ L L J KOPPES ${ }^{\mathrm{b}, \mathrm{c}}$ H C G KEMPER $^{\mathrm{b}}$ \\ K D MONYEKI ${ }^{\mathrm{d}}$ J W R TWISK $^{\mathrm{b}, \mathrm{e}}$ \\ a Curriculum and Professional Studies, School of Education, \\ University of Limpopo, Sovenga, SOUTH AFRICA \\ $b$ EMGO, Institute, VU University Medical Center, \\ Amsterdam, The NETHERLANDS \\ ${ }^{c}$ Department of Public and Occupational Health, VU University \\ Medical Center, Amsterdam, The NETHERLANDS \\ $d$ Medical Research Council, Cape Town, SOUTH AFRICA \\ $e$ Department of Clinical Epidemiology and Biostatistics, \\ VU University Medical Center, Amsterdam, The NETHERLANDS
}

\author{
MJ 菲文尼 ${ }^{\mathrm{a}} \quad$ LLJ 高巴斯 ${ }^{\mathrm{b}, \mathrm{c}} \quad$ HCG 金巴 ${ }^{\mathrm{b}}$

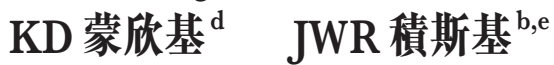 \\ ${ }^{a}$ 南非林布布大學敎育系課程及專業學院 \\ ${ }^{b}$ 荷蘭VU大學醫學研究中心 \\ c 荷蘭VU大學公共及職業健康系 \\ d 南非醫學研究局 \\ $\mathrm{e}$ 荷蘭VU大學醫學院流行病學系
}

\begin{abstract}
The purpose of the present study was to investigate the development, tracking and longitudinal relationships of nutritional status, body composition and educational achievements in rural South African children in 459 boys and 354 girls who participate in the Ellisras Longitudinal Study. Nutritional status, body composition and educational achievements were measured in 2001 and 2002. The results showed that: 1) Height for age (HAZ) decreased significantly over the oneyear period whereas Weight for Age (WAZ), Body mass index (BMI) and Sum of skinfolds (SOS) did not change, and the Mathematics and English achievements increased over the one-year period. 2) High tracking coefficients were found for HAZ, WAZ, BMI, while SOS showed low to moderate tracking and Mathematics and English showed no tracking. 3) Significant relationships between changes in nutritional status and changes in educational achievements were found for boys only.
\end{abstract}

\section{摘 要}

本文旨在探討南非鄉鎮地區小學生身體營養水平與學業的關係。以問卷方式進行調查，訪問了813名學童，並評估他們的營 養狀況。結果顯示出男生的營養水平與學業呈現關係。 


\section{Introduction}

Many children in the developing world live under marginal and inadequate nutritional conditions, primarily with deficiency in protein, energy intake and also vitamin A and iron deficiency (Steyn \& Walker, 2000). This often results in malnutrition. Malnutrition has always been recognized as one of the major contributors to poor educational achievements with hundreds affected every year (Themane et al., 2003). In South Africa communities that were previously disadvantaged like Ellisras are the most affected (Monyeki, 2000). One way of fighting malnutrition is by improving the educational levels of these communities (Franco, 2001). Studies have linked malnutrition to poor educational achievements (Hansford \& Hattie, 1982; Pollitt, 1995). These studies suggest that malnutrition leads to poor educational achievements. However, what is not clear yet is how this relationship is on a longer period. To date, these studies about the relationships between malnutrition or body composition were cross-sectional in nature and therefore relatively sensitive to bias.

In an earlier publication we used cross-sectional data from the Ellisras Longitudinal Study (ELS) and found that children with better nutritional status have better educational achievements (Themane et al., 2003). It is however an important question to know whether an improvement in nutritional status over time is associated with an improvement in educational achievement. To answer this question, a longitudinal study is needed and the Ellisras Longitudinal Study provides the unique possibility to answer this question. Therefore the aim of the present study was to investigate the development and tracking of nutritional status, body composition and educational achievements and the longitudinal relationships of these over a one-year period of follow-up in rural South African children.

\section{Methods}

\section{Subjects}

The Ellisras Longitudinal Study started in 1996 with yearly measurements in 8 birth cohorts of pupils from 22 primary schools in the Ellisras region. Two sets of educational achievements measurements were added in May/June 2001 and 2002 to the standard set of ELS measurements that include measures of nutritional status and body composition.

\section{Measurements}

\section{Anthropometry}

Height and weight were measured according to the standard procedures described by the International Society for the Advancement of Kinanthropometry (ISAK) (Norton and Olds, 1996). A Martin anthropometer was used to measure height to the last complete $0.1 \mathrm{~cm}$ and Schoenl electronic scales to measure weight to the last complete $0.1 \mathrm{~kg}$. A Harpenden (John Bull) skinfold caliper with inter-jaw pressure of $10 \mathrm{~g} / \mathrm{mm} 2$ was used to measure the thickness of the triceps, biceps, subscapular and supraspinale skinfolds to the nearest $0.2 \mathrm{~mm}$. Body Mass Index (BMI) and the sum of four skinfolds (SOS) were used as indicators of body composition. Height-for-age (HAZ) and weight-for-age (WAZ) values were calculated on the basis of the NHANNES II reference sample (Frisancho, 1990) and were used as indicators of nutritional status. More details on the measurement procedures used in this study have been described in earlier publication from ELS (Monyeki \& Toriola, 1997).

\section{Educational Achievements}

The educational achievements were based on the Human Sciences Research Councils' Educational Achievement Tests in Mathematics and English (HSRC, 1995). These tests are standardized for South African school children. The help of an educational psychometrist was employed in the administration of the tests. Tests were administered to the pupils who had completed the previous grade syllabus. For example, the test for grade 5 was taken by those pupils who had already passed that grade and were in grade 6. The tests were administered as early in the day as possible before children could be fatigued by previous lessons. An attempt was made to motivate the pupils, by assuring them that these tests were not meant for examination purposes, arouse their interest, obtain their cooperation and make them feel at ease in order to achieve the best results.

The English test contained two sections. Subtest 1 was about vocabulary and reading comprehension, and it lasted for 30 minutes. Subtest 2 was about writing-related skills and language usage and lasted for 23 minutes. The English score was the addition of the two subtests. The Mathematics test had only one section, which lasted for 60 minutes. The range of possible score was 0 to 60 for English and 0 to 30 for Mathematics, where high score indicates good performance. 


\section{Statistical Analysis}

Only the children with completed both sets of data on nutritional status, body composition and educational achievement in for both 2001 and 2002 measurements were included in the analysis.

Changes over time in nutritional status and educational achievements were analyzed with paired ttests. Pearson correlations with adjustments for age were calculated to study the tracking of nutritional status, body composition and educational achievements. Multi level linear regression analyses were performed to investigate age-adjusted relationships between one-year changes in nutritional status, body composition and educational achievements. All analyses were performed separately for boys and girls. Multilevel techniques were used because the pupils are clustered within classes.

\section{Results}

The Development of Nutritional Status, Body Composition and Educational Achievements over the One-year Period of Follow up

Table 1 shows descriptive information for nutritional status, body composition and educational achievements at the two measurements points. A significant decrease in HAZ was found for both boys and girls. The body composition measures for BMI showed a significant increase, whereas SOS showed a significant decrease. Boys showed a significant improvement in English and Mathematics, while girls showed a significant improvement only in Mathematics.

Table 1. Means and Standard Deviations (SD) of Nutritional Status, Body Composition and Educational Achievement for Boys and Girls at the First Measurement in 2001 and the Second Measurement in 2002.

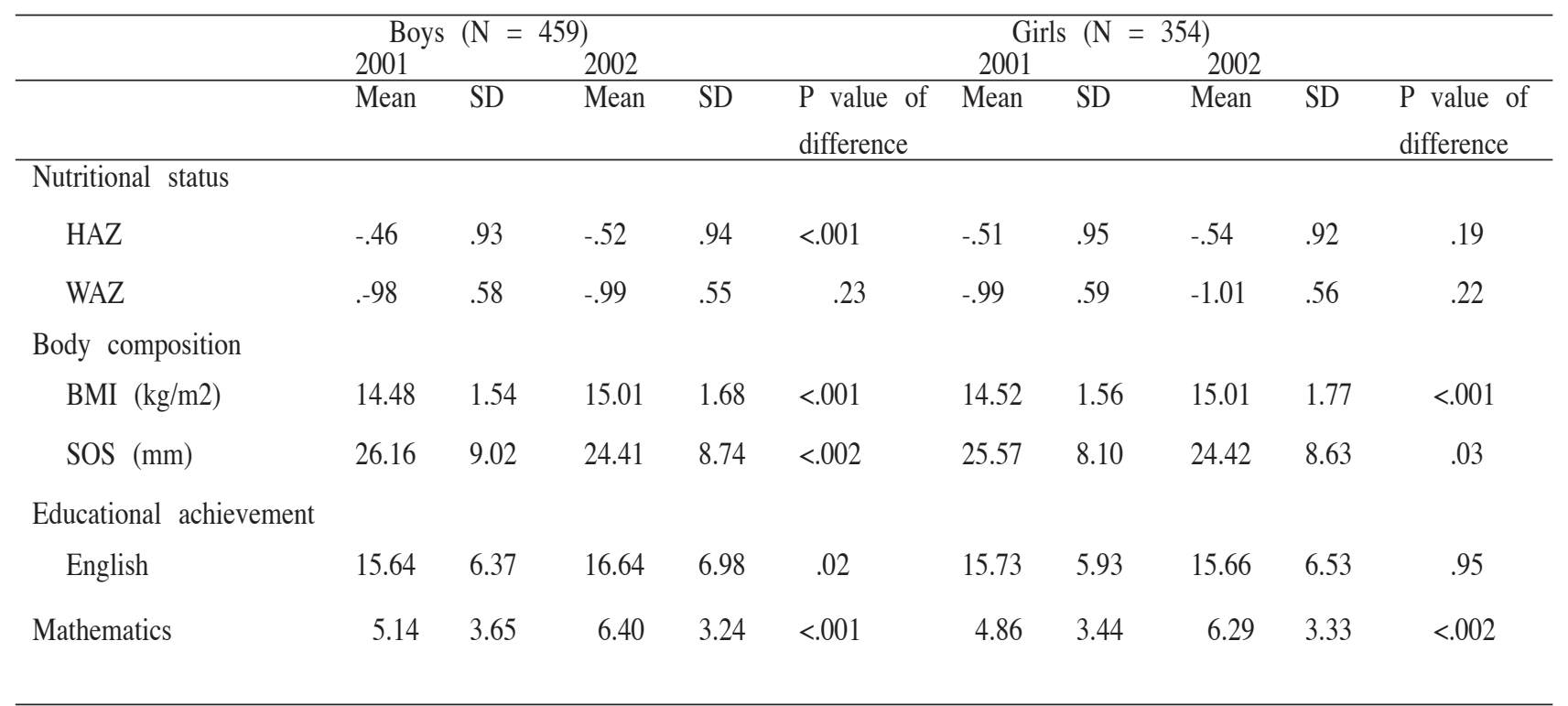

$\mathrm{HAZ}=$ height-for-age $\mathrm{z}$-score, $\mathrm{WAZ}=$ weight-for-age $\mathrm{z}$-score, BMI = body mass index, $\mathrm{SOS}=$ Sum of skinfolds 
Tracking of Nutritional Status, Body Composition and Educational Achievements over One-year Period

Table 2 shows tracking coefficients over the one-year period for nutritional status indicators, body composition and educational achievements. HAZ, WAZ, and BMI showed high tracking coefficients; whereas for SOS a low to moderate tracking coefficient was found. For both English and Mathematics very low tracking coefficients were observed.

Table 2. Tracking Coefficients of Nutritional Status, Body Composition and Educational Achievement.

\begin{tabular}{lllll}
\hline & $\begin{array}{l}\text { Boys } \\
\text { Tracking } \\
\text { coefficients }\end{array}$ & $\mathrm{p}$ value & $\begin{array}{l}\text { Girls } \\
\text { Tracking } \\
\text { coefficients }\end{array}$ & $\mathrm{p}$ value \\
\hline Nutritional status & .93 & $<.001$ & .94 & $<.001$ \\
HAZ & .85 & $<.001$ & .88 & $<.001$ \\
WAZ & & & \\
Body composition & .90 & $<.001$ & .89 & $<.001$ \\
BMI & .31 & $<.001$ & .28 & $<.001$ \\
SOS & & & .03 & .60 \\
Educational achievement & .07 & .15 & -.02 & .82 \\
English & .02 & .82 & -02 & \\
Mathematics & & & & \\
\hline
\end{tabular}

$\mathrm{HAZ}=$ height-for-age $\mathrm{z}$-score, WAZ = weight-for-age $\mathrm{z}$-score, $\mathrm{BMI}=$ body mass index, $\mathrm{SOS}=$ Sum of skinfolds

The Relationship of Changes in Nutritional Status and Body Composition with Changes in Educational Achievement over One-year Period of Follow up

Table 3 presents the regression coefficients of the age adjusted relationships of changes in nutritional status, body composition and changes in educational achievements.
Significant positive relationships were found between SOS and Mathematics in boys. Further, a borderline significant positive association was observed between WAZ and Mathematics in boys. No significant relationships were found for English or Mathematics in girls.

Table 3. Age Adjusted Standardized Regression Coefficients (b) and P-values for the Relationship of Changes in Measures of Nutritional Status and Body Composition with Changes in Educational Performance Controlled for Age.

\begin{tabular}{|c|c|c|c|c|c|c|c|c|}
\hline & \multicolumn{4}{|l|}{ Boys } & $\begin{array}{l}\text { Girls } \\
\text { Englis }\end{array}$ & & Mathe & \\
\hline & B & $p$ & $\mathrm{~b}$ & $\mathrm{P}$ & $\mathrm{b}$ & $\mathrm{p}$ & $\mathrm{b}$ & p \\
\hline HAZ & -0.01 & .89 & 0.07 & .58 & -0.01 & .45 & 0.11 & .20 \\
\hline WAZ & -0.03 & .61 & 0.16 & .08 & 0.02 & .78 & -0.08 & .47 \\
\hline BMI $(\mathrm{kg} / \mathrm{m} 2)$ & -0.03 & .60 & 0.04 & .70 & 0.05 & .40 & 0.02 & .77 \\
\hline SOS (mm) & -0.05 & .38 & 0.24 & .01 & 0.01 & .94 & 0.06 & .53 \\
\hline
\end{tabular}

HAZ = height-for-age z-score, WAZ = weight-for-age $\mathrm{z}$-score, BMI = body mass index, SOS = Sum of skinfolds 


\section{Discussions}

The main findings of this longitudinal study are: 1) Nutritional status indicators decreased significantly over one-year period. A significant increase was found for English and Mathematics except for Mathematics in girls. 2) High tracking coefficients were found for HAZ, WAZ, BMI, while SOS showed low to moderate tracking coefficients. Low tracking coefficients were found for both English and Mathematics. 3). There were few significant relationships between changes in nutritional status, body composition and changes in educational achievements especially in boys.

\section{The Development of Nutritional Status, Body Composition and Educational Achievements over the One-year Period}

Longitudinal studies on developmental changes in nutritional status, body composition and educational achievements during childhood are limited, especially in South Africa. The study that comes closest to ours is that of Mendez and Adair (1999) which evaluated wasting and stunting and its associations with educational achievements over a period of two years. This study found significant developments in nutritional status. Another study is that of Cameroon et al. (2005) which looked at the development of African urban children who stunted at 2 years of age after ages 5 and 7 . This study also found significant changes over time.

Lack of significant developments in nutritional status and some of the body measures in the present study is hard to explain there were substantial especially there has been some improvements brought about by intervention school nutrition programmes from the Department of Health and Social Development (1996). Perhaps the period was two short to warrant any significant differences.

Developmental changes in educational achievements measures over a period of one year are line with other studies elsewhere. Murphy et al. (1998) found that children's performances in mathematics when studied over time showed improvements. The changes in the educational achievements in the present study may indicate that this population has improved as a result of educational provisions which have been channeled to the education sector (Department of Education, 2002). In literature comparable findings were reported by Galler et al. (1987), and Chopra and Sharma (1992) who found that when social conditions improved educational outcomes improved as well.

However, this comparison should be made with some caution because comparing children's educational outcomes in South Africa with findings from other African countries may not lead to similar conclusions given South Africa's history of racially based educational policies that differentially influenced schooling opportunities at the individual and community levels. From a racial stratification perspective, South Africa offers a very different social, economic and political context as compared to the rest of sub-Saharan Africa. Hence further research on the causes of educational achievements will enhance our understanding of the complexities associated with the process of educational attainment in a developing country

\section{Tracking of Nutritional and Educational Achievement over One-year Period}

Nutritional status components showed high tracking coefficients except for sum of skinfolds. The low tracking coefficient for skinfolds may be explained by measurement error, because skinfolds thickness is probably measured with more error than for instance BMI Growth and maturation may be the other explanatory reason for low tracking coefficients (Malina, 1990). No comparable studies that investigated tracking of nutritional status in rural children were found. Educational achievements showed absolute no tracking which is rather strange. This implicates that children with high scores at the first measurement did not have high scores at the second measurement. One can speculate whether measurement error is responsible for these very low tracking coefficients, but that can not be the whole story. Maturation can also be partly responsible, but both arguments are highly speculative, which is also due to the fact no other studies were found that investigated tracking of educational achievements.

\section{The Relationship between Changes in Nutritional Status, Body Composition and Changes in Educational Achievement over One- year Period}

Because in our previous cross-sectional study on the same population we found that the nutritional and body composition indicators were significantly related to both English and Mathematics (Themane et al., 2003), the present results regarding the relationship between changes 
in these parameters were not what we had expected. It is hard to explain these findings, especially because to our knowledge there are no comparable studies performed.

Several studies link childhood malnutrition to adverse schooling outcomes, (Daniels \& Adair, 2004; Mendez \& Adair, 1999), but they are all different from our study. Daniels and Adair (2004), for instance, explored the association between HAZ at 2 years and schooling outcomes (entrance age, grade repetition, and grades completed) among 2198 children from the Cebu Longitudinal Health and Nutrition Survey Parity and found no significant relationships. They found that the results of stunting alone were not associated with educational outcomes at a later stage. However, the problem they encountered was that those who had a complete analysis data came from poorer families and thus they could not pronounce with confidence that HAZ was or was not significantly related to educational achievements of children. They therefore argued that lack of significant results might have been caused by other factors such as parental education, maternal height, household assets, environmental cleanliness, presence of electricity, and household income. To check for such affects they performed adjusted sessions of schooling outcomes. After adjustment significant associations were found between HAZ and schooling outcomes.

Although HAZ was associated with retention and promotion in school, a causal relation remains unproven. The quality of much of the current research is limited by the use of cross-sectional data and inadequate control of potential confounders. The extent and nature of this relation, the pathways through which its most influential effects occur, and the extent to which early childhood nutrition interventions improve schooling outcomes are still unclear.

The question remains: Why there are significant relationships between absolute values of nutrition and educational achievements and not between the changes in these variables?

The only explanation we can think of is that the period between the two measurements was too short to be able to see significant changes. Educational achievements, by their very nature, take a bit of time before significant changes can be realized.
In conclusion, the results of the present study showed that, in general, educational achievement increased over time, that tracking of educational achievements were very low, and that one-year changes in nutritional status were not associated with one-year changes in educational achievements.

\section{References}

Cameroon, N., Wright, N.M, Griffiths, P. L, Norris, S. A, \& Pettifor, J.M (2005). Stunting at 2 years in relation to body composition at 9 years in African urban children. Obesity Research 13 (1) 131-6.

Chopra, J. S., \& Sharma, A. (1992). Protein energy malnutrition and the nervous system. Journal of Neurological Sciences 110, 8-20.

Daniels, M.C., \& Adair, L.S (2004). Growth in Young Filipino Children predicts Schooling Trajectories through High School. J. of Nutr. 134, 1439-1446.

Department of Health and Social Development. (1996). Child Support Grant. Pretoria Government Press.

Department of Education. (2002). Finance Minister Trevor Manuel's Budget Speech. Pretoria: Government Press.

Franco, K., (2001). Optimizing nutritional health for children through school-based initiatives. Journal of the American Dietetic Association, 101(8), 873-74.

Frisancho, A. R. (1990). Anthropometric Standards for the Assessment of Growth and Nutritional Status. MI: The University of Michigan Press.

Hansford, B. C., \& Hattie, J. A. (1982). The relationship between self and achievement/performance measures. Review of Educational Research 52, 123-142.

Harris, K. (2002). The USDA School Lunch Program, Clearing House, Jul/Aug 2002, 75, (6), 310.

Human Sciences Research Council. (1995). Educational Achievement Tests. Pretoria: HSRC.

Galler, J. R, Ramsey, F. C, Forde, V., Salt, P., \& Archer, E., (1987). Long -term effects of early kwashiorkor compared with marasmus. II. Intellectual Performance. Journal of Ped. Gastro Nutrition, 6 (6), 847-854. 
Malina, R.M. (1990). Tracking of physical fitness and performance during growth. In: Beunen G., Ghesquiere J., Reybrouck T., Claessens A.L., (editors) Children and Exercise. Stuttgart: Ferdinand Enke Verlag, 1990, 1-10.

Martorell, R. (1995). Results and implications of the INCAP follow-up study. J of Nutr. 125(suppl), S1127 $-\mathrm{S} 1138$.

McCoy, D. (1997). An Evaluation of the Primary School Nutrition Programme, Durban: Health Systems Trust

McLachlan, M., \& Kuzwayo, P. (1997). Bold Choices: Making the South African Nutrition Strategy Work, Development Paper No.128, Development Bank of Southern Africa.

Mendez, M.A.,\& Adair, L. S (1999). Severity and Timing of Stunting in the First Two Years of life Affect Performance on Cognitive Tests in Late Childhood. $J$ of Nutr, 129, 1555-1562.

Monyeki, K. D., \& Toriola, A. L. (1997). Anthropometric assessment of nutritional status of South African Molepo boys. African Journal for Physical, Health Education, Recreation and Dance 3(2), 228-239.

Monyeki, K. D. (2000). Tracking physical Growth and Health Status of South African Rural Children: Ellisras Longitudinal Study (ELS). PhD Thesis. Potchefstroom University for CHE. Potchefstroom.

Murphy, J. M., Pagano, M.E., Nachmani, J., Sperling, P., \& Kleinman, R. E. (1998). The relationship of school breakfast to psychological and academic functioning. Archives of pediatrics and Adolescents Medicine, 101 (10)E3.

Norton, K., \& Olds, T. (1996). Anthropometrica. Marvikville: South Wood Press.

Pollitt, E. (1993). Nutrition and educational achievement, Nutrition Education Series, Issue 9, UNESCO.

Pollitt, E. (1995). Malnutrition and Infection in the Classroom, UNESCO.
Schroeder, D.G, Martorell, R., Rivera, J.A., Ruel, M.T., \& Habicht, J.P. (1995). Age differences in the impact of nutritional supplementation on growth. $J$ of Nutr. 125(suppl), S1051 -S1059.

Steyn, N.P., Robertson, H. L., Mekhuria, M., \& Labadarois, D. (1998). Household security-What health professionals should know. South African medical Journal, 88 (1), 75-79.

Themane, M.J. Monyeki, K.D. Nthangeni, M.E. Kemper, H.C.G., \& Twisk, J.W.R.(2003). The relationship between health (malnutrition) and educational achievement (Maths and English) in the rural children of South Africa. Inter. J. of Educ. Dev. 23, 637-643.

\section{Correspondence:}

Dr. M J Themane

Address: P O Box 5182, POLOKWANE NORTH 0750, SOUTH AFRICA 